\title{
First study conducted in Northern India that identifies group $C$ rotavirus as the etiological agent of severe diarrhea in children in Delhi
}

Vasundhara Razdan Tiku², Baoming Jiang ${ }^{3}$, Praveen Kumar ${ }^{4}$, Satender Aneja ${ }^{4}$, Arvind Bagga², Maharaj Kishen Bhan ${ }^{2}$ and Pratima Ray ${ }^{1 *}$ (i)

\begin{abstract}
Background: Group C Rotavirus (RVC) is an enteric pathogen responsible for acute gastroenteritis in children and adults globally. At present there are no surveillance studies on group C Rotaviruses in India and therefore their prevalence in India remains unknown. The present study aimed to evaluate group $C$ rotavirus infection among $<5$ years old children hospitalized with acute gastroenteritis in New Delhi.
\end{abstract}

Methods: A total of 350 fecal specimens were collected during September 2013 to November 2014 from $<5$ years old diarrheal patients admitted at KSCH hospital, Delhi. The samples found negative for group A rotavirus $(N=180)$ by Enzyme immunoassay were screened for group C rotavirus by RT-PCR with VP6, VP7 and VP4 gene specific primers. The PCR products were further sequenced (VP6, VP7, VP4) and analyzed to ascertain their origin and G and P genotypes.

Results: Six out of 180 (group A rotavirus negative) samples were found positive for group C rotavirus by VP6 gene specific RT-PCR, of which 3 were also found positive for VP7 and VP4 genes. Phylogenetic analysis of VP7 and VP4 genes of these showed them to be G4 and P[2] genotypes. Overall, the nucleotide sequence data (VP6, VP7 and VP4) revealed a close relationship with the human group $C$ rotavirus with no evidence of animal ancestry. Interestingly, the nucleotide sequence analysis of various genes also indicated differences in their origin. While the identity matrix of VP4 gene $(n=3)$ showed high amino acid sequence identity (97.60 to 98.20\%) with Korean strain, the VP6 gene $(n=6)$ showed maximum identity with Nigerian strain (96.40 to $97.60 \%)$ and VP7 gene $(n=3)$ with Bangladeshi and USA strains. This is true for all analyzed samples.

Conclusion: Our study demonstrated the group C rotavirus as the cause of severe diarrhea in young children in Delhi and provides insights on the origin of group C rotavirus genes among the local strains indicating their source of transmission. Our study also highlights the need for a simple and reliable diagnostic test that can be utilized to determine the disease burden due to group C rotavirus in India.

Keywords: Diarrhea, Children, Group C Rotavirus, Gastroenteritis, Phylogenetic analysis, Sequence identity matrix

\footnotetext{
* Correspondence: pratimaray.aiims@gmail.com

'Department of Biotechnology, Faculty of Science, Jamia Hamdard University,

Hamdard Nagar, New Delhi 110062, India

Full list of author information is available at the end of the article
} 


\section{Background}

Group C rotavirus (RVC) is an important etiologic agent of dehydrating diarrhea in humans and animals. It belongs to the genus Rotavirus within the family Reoviridae. Group C Rotaviruses were first detected in piglets with diarrhea in 1980 in USA [1] and their association with the human diarrheal disease was confirmed in 1982 [2]. Thereafter, a number of studies have showed association of group $\mathrm{C}$ rotaviruses in many diarrheal outbreaks all over the world [3-7]. The genetic reassortment between porcine RVC and bovine/human RVC were reported earlier [8, 9]. These viruses have also been reported in cases with extrahepatic biliary atresia [10] in which one or more bile ducts are abnormally narrow, blocked or absent. The more vulnerable age for getting group $\mathrm{C}$ rotavirus infection is $\geq 4$ years [11] as compared to group A rotavirus where children of less than 3 years of age are at greater risk of getting infected $[12,13]$.

The prevalence of the group $\mathrm{C}$ rotavirus as an etiologic agent of severe diarrhea and the epidemiology of RVC infection is limited due to lack of proper diagnostic assays. The techniques like electron microscopy require a dedicated laboratory set up and cannot be used in a clinical setup for routine detection. Moreover it can identify virus only when present in high concentration and cannot differentiate between group $\mathrm{A}$ and group $\mathrm{C}$ rotaviruses. Group $\mathrm{C}$ rotaviruses are shed in low level and often appear unstable in the stool; therefore RNA may go undetected in the polyacrylamide gel electrophoresis (PAGE). An antigen based Enzyme linked immunosorbant assay (ELISA) using RVC specific antibodies may prove a more sensitive and reliable method for detecting group $\mathrm{C}$ rotavirus. The molecular methods like Reverse transcriptase polymerase chain reaction (RT-PCR) with gene specific primers followed by gene sequencing and sequence analysis are more reliable and sensitive tools for the genotyping and characterization of group $\mathrm{C}$ rotaviruses [11, 14]. Sequencing followed by phylogenetic analysis of group $\mathrm{C}$ viral gene segments offers a better approach for detection of the virus and the investigation of possible evolutionary relationship with other species [15]. This system has provided a reliable platform for determining the origin and comparing the different strains of rotaviruses [16].

The prevalence of group $C$ rotavirus in India remains largely unknown. Therefore the present study was conducted to identify and characterize group $\mathrm{C}$ rotavirus in children suffering from acute gastroenteritis admitted in Kalawati Saran Children Hospital $(\mathrm{KSCH})$ in Delhi. RT-PCR followed by sequence analysis was performed to understand its origin and genetic association with other RVC strains reported from different geographical regions globally.

\section{Methods}

\section{Study sample}

A total of 350 fecal specimens were collected between September 2013 and November 2014 from pediatric patients of $<5$ years admitted with acute gastroenteritis at dedicated child care center "Kalawati Saran Children Hospital" in Delhi as a part of the Rotavirus surveillance study. A written informed consent was obtained from one of the parents of the child before enrollment. All (350) children with diarrhea of less than 3 days duration were screened for group A rotavirus [17]. The remaining group A rotavirus (RV) negative (180) fecal specimens were stored in a deep freezer $\left(-80{ }^{\circ} \mathrm{C}\right)$ for further testing. The study was ethically approved by the institute ethics committee.

\section{RNA extraction and cDNA synthesis}

The dsRNA was extracted from $10 \%$ fecal suspension by Trizol method (Invitrogen Corp, Carlsbad, CA) following manufacturer's instructions. The complementary DNA (cDNA) was synthesized from the RNA using random hexameric primers and moloney murine leukemia virus (M-MLV) reverse transcriptase (Invitrogen Life Technologies). The random priming was carried out by incubation at $37{ }^{\circ} \mathrm{C}$ for one hour, followed by $5 \mathrm{~min}$ incubation at $95{ }^{\circ} \mathrm{C}$. The cDNA was further utilized for group C VP6, VP7 and VP4 gene amplification.

\section{PCR Amplification of VP6, VP7 and VP4 genes}

Two-step PCR (VP4/VP6/VP7) was carried out, with the first step as full-length gene (VP6/VP7/VP4) amplification with consensus primers (forward and reverse) followed by a nested PCR using the first PCR product and the internal primer(s) [Table 1]. This strategy was adopted to increase the sensitivity of PCR. Further, to reduce the cost of reagents and primers the PCR was carried out first in a pool of 5 cDNA samples (3ul each) and then individual sample from positive pool(s) were retested with gene specific primers [Table 1]. Typically, the PCR mix was prepared containing $2.25 \mathrm{ul}$ of $10 \times$ buffer II, $2.0 \mathrm{ul}$ of $25 \mathrm{mM} \mathrm{MgCl} \mathrm{m}_{2}, 0.5 \mathrm{ul}$ of $10 \mathrm{mM} \mathrm{dNTP}$ mix, 0.1 ul of $5 \mathrm{U} / \mathrm{ul}$ Taq polymerase (Invitrogen Life Technologies) and $0.5 \mathrm{ul}$ of each $20 \mathrm{um} / \mathrm{ul}$ of primers to obtain the final reaction volume of $25 \mathrm{ul}$ [18]. The PCR was conducted with the condition of initial denaturation at $94{ }^{\circ} \mathrm{C}$ for $3 \mathrm{~min}, 30$ cycles of $94^{\circ} \mathrm{C}$ for $1 \mathrm{~min}$, $45{ }^{\circ} \mathrm{C}$ for $2 \mathrm{~min}$ and $72{ }^{\circ} \mathrm{C}$ for $3 \mathrm{~min}$ and final extension at $72{ }^{\circ} \mathrm{C}$ for $7 \mathrm{~min}$. Any change in annealing temperature is specified below. VP6 (1353 bp) full length gene was amplified using VP6 FP-1/BMJ-44. For the nested PCR, BMJ-145 and BMJ-144 were used as internal forward and reverse primer respectively $[14,18]$. The nested PCR was carried out at $53{ }^{\circ} \mathrm{C}$ annealing temperature [18]. 
Table 1 List of primers used for PCR amplification of group C rotavirus Group C Rotavirus positive controls were provided by Dr. Baoming Jiang, Gastroenteritis \& Respiratory Viruses Lab, Division of Viral Diseases, Centers for Disease Control and Prevention, Atlanta

\begin{tabular}{|c|c|c|c|c|}
\hline Gene & Primer (Polarity) & Sequence $\left(5^{\prime}-3^{\prime}\right)$ & Position & Reference \\
\hline \multirow[t]{4}{*}{$\overline{V P 7}$} & \multirow{2}{*}{$\begin{array}{l}\text { VP7 FP-1 } \\
\text { BMJ-13 }\end{array}$} & \multirow{2}{*}{$\begin{array}{l}\text { 5'-GGC ATT TAA AAA AGA AGA AGC TG-3' } \\
\text { 5'-AGC CAC ATG ATC TTG TाT -3' }\end{array}$} & $1-23$ & \multirow[t]{2}{*}{ Jiang et al.,1995 } \\
\hline & & & $1063-1046$ & \\
\hline & \multirow{2}{*}{$\begin{array}{l}\text { BMJ-107 } \\
\text { BMJ-13 }\end{array}$} & \multirow{2}{*}{$\begin{array}{l}\text { 5' TGT TTG GAG ATG TGA TGA -3' } \\
\text { 5'-AGC CAC ATG ATC TTG TाT-3' }\end{array}$} & $546-563$ & \multirow[t]{2}{*}{ Jiang et al.,1995 } \\
\hline & & & $1063-1046$ & \\
\hline \multirow[t]{4}{*}{ VP6 } & \multirow{2}{*}{$\begin{array}{l}\text { VP6 FP-1 } \\
\text { BMJ-44 }\end{array}$} & \multirow{2}{*}{$\begin{array}{l}\text { 5'- GCA TाT AAA ATC TCA TTC ACA A-3' } \\
\text { 5'-AGC CAC ATA GTT CAC ATT TCA-3' }\end{array}$} & $2-22$ & \multirow[t]{2}{*}{ Jiang et al.,1995 } \\
\hline & & & 1353-1333 & \\
\hline & \multirow{2}{*}{$\begin{array}{l}\text { BMJ-145 } \\
\text { BMJ-144 }\end{array}$} & \multirow{2}{*}{$\begin{array}{l}\text { 5'-AGT CCG TTC TAT GTG ATT C-3' } \\
\text { 5'-CCT TCT GGG GAT CAT CCA T-3' }\end{array}$} & 1014-1032 & \multirow[t]{2}{*}{ Jiang et al.,1995 } \\
\hline & & & $1331-1313$ & \\
\hline \multirow[t]{4}{*}{ VP4 } & \multirow{2}{*}{$\begin{array}{l}\text { GCVP4-1FP } \\
\text { GCVP4-12RP }\end{array}$} & \multirow{2}{*}{$\begin{array}{l}\text { 5'- GGC TTA AAA AAT AGA GAT CGA TGG CG -3' } \\
\text { 5'- CAT AAA CAA GTT GCA ACC TTG ATG -3' }\end{array}$} & $1-26$ & \multirow{2}{*}{$\begin{array}{l}\text { Yamamoto et al. } \\
2011\end{array}$} \\
\hline & & & $1275-1252$ & \\
\hline & \multirow{2}{*}{$\begin{array}{l}\text { GCVP4-2FP } \\
\text { GCVP4-12RP }\end{array}$} & \multirow{2}{*}{$\begin{array}{l}\text { 5'- GTA AGG ACT CAT TGT GGC AAG A -3' } \\
\text { 5'- CAT AAA CAA GTT GCA ACC TTG ATG -3' }\end{array}$} & $843-820$ & \multirow{2}{*}{$\begin{array}{l}\text { Yamamoto et al. } \\
2011\end{array}$} \\
\hline & & & $1275-1252$ & \\
\hline
\end{tabular}
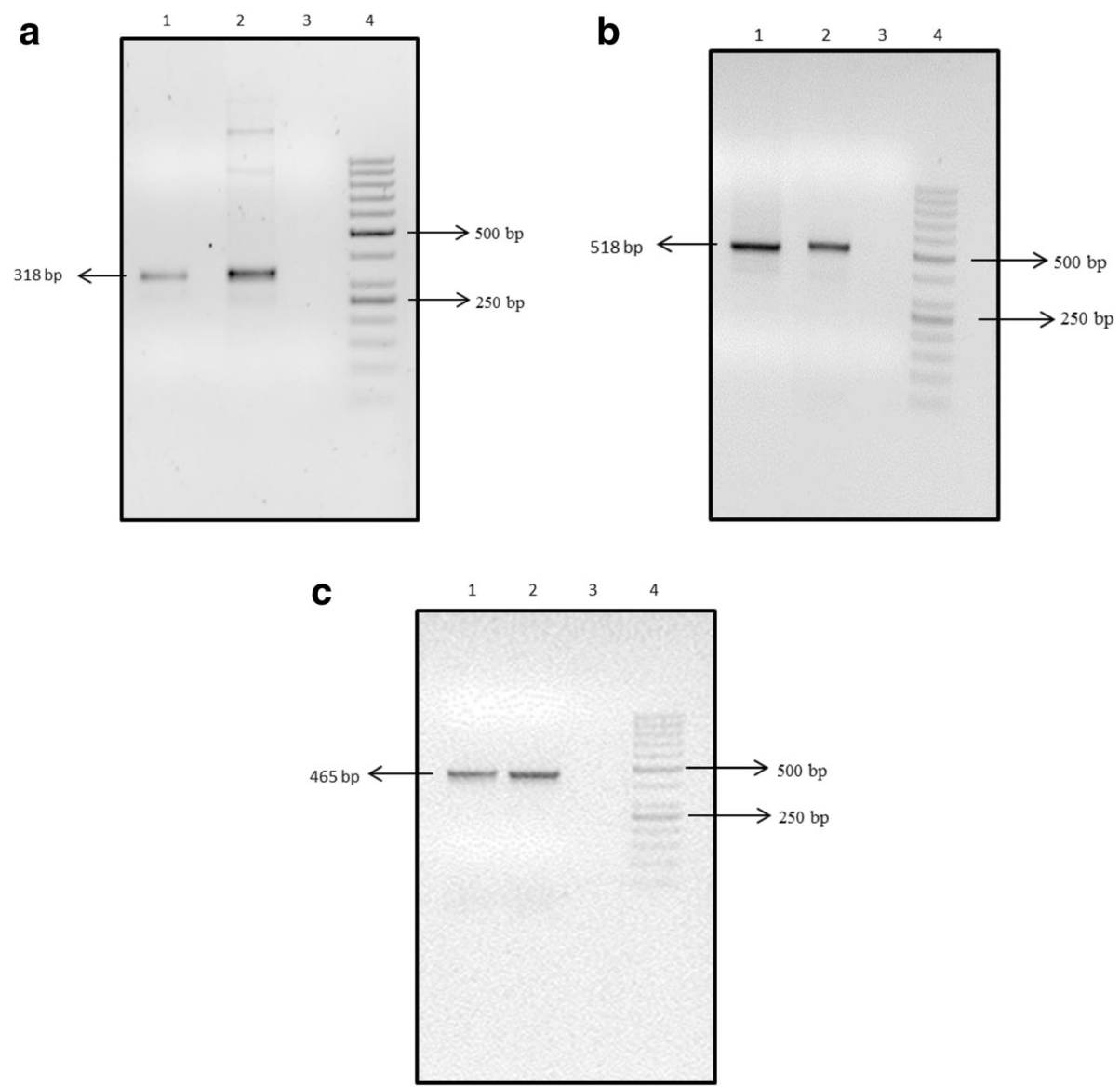

Fig. 1 RT- PCR results of group C rotavirus (a): VP6 gene (b): VP7 gene and c: VP4. The amplicons were analyzed on 2\% agarose gel stained with ethidium bormide. a Lane 1: Sample ND-056, lane 2: positive control, lane 3: negative control and lane 4: 50 bp molecular weight marker. b Lane 1: sample ND-061, lane 2: positive control, Lane 3: negative control and lane 4: 50 bp molecular weight marker. c Lane 1: Sample ND-061, Lane 2: positive control, lane 3: negative control and lane 4: 50 bp molecular weight marker 
The full-length VP7 (1063 bp) gene was amplified with VP7 FP-1/BMJ-13 primers. The semi-nested PCR (518 bp) was carried out using the first round product as the template with forward BMJ-107 and reverse BMJ-13 primers [14, 18]. The annealing temperature for VP7 nested PCR was $48{ }^{\circ} \mathrm{C}$. The full-length VP4 gene (1275 bp) was amplified with GCVP4-1FP/ GCVP4-12RP primers while for the partial gene (456 bp), GCVP4-2FP and GCVP4-12RP primers were used [9]. The annealing temperature was performed at $52{ }^{\circ} \mathrm{C}$ for both first and second round PCR. The primers used for the amplification of VP6, VP7 and VP4 genes are listed in table 1 . The PCR products were then analyzed on $2 \%$ agarose gel.

\section{Statistical analysis}

The Student t-test was performed to assess the distribution of variables using STRATA version 12. Various clinical parameters such as age, days and episodes of diarrhea and vomiting have been described in terms of mean and standard deviation; the dehydration and treatment variables are presented as percentages.

\section{Results}

\section{Rotavirus detection}

A total of 180 of 350 fecal samples previously collected from diarrheal children ( $<5$ years) and tested negative for group A rotavirus (RVA) by Rotaclone ELISA were screened for group C rotavirus by RT-PCR. Six of 180 were found positive for VP6 gene with the prevalence rate of 3.33\%. Further 3 out of 6 were found positive for VP4 and VP7 genes [Fig. 1a, b and c].

\section{Phylogenetic and sequence analysis of VP6 gene}

Phylogenetic analysis of VP6 gene $(n=6)$ with reference strains showed clustering with Nigerian and Chinese human RVC [Fig. 2]. A maximum homology both at nucleotide (98.6 to $99.7 \%$ ) as well as amino acid (96.4 to $97.60 \%)$ level was observed with the Nigerian strain 'jajeri' and relatively less homology (90.60 to $93.00 \%$ nucleotide and 95.10 to $96.60 \%$ for amino acid) was observed with previously reported Indian strains [Table 2]. Overall high VP6 sequence homology was generally seen with most human RVC strains as compared to those of animal rotavirus strains. For example: 92.10 to $96.20 \%$ (amino acid) homology was observed with other human strains as compared to 60.20 to $67.60 \%$ (amino acid) homology with bovine and porcine strains respectively. Among the study sample, ND-204, ND-240 and ND-398; ND-056, ND-061 and ND-237 were found identical with respect to VP6 gene [Table 2].

\section{Phylogenetic and sequence analysis of VP7 gene}

The phylogenetic dendrogram of VP7 showed the infecting RVC strains $(n=3)$ clustering into a single genotype "G4", which is the only human RVC genotype. The ND-240 strain showed close genetic relationship with USA strain while ND-061 and ND-237 clustered with Bangladeshi human RVC strains [Fig. 3]. The VP7 gene of the present RVC strains revealed 98.0 to $99.20 \%$ at nucleotide and 95.70 to $97.60 \%$ at amino acid

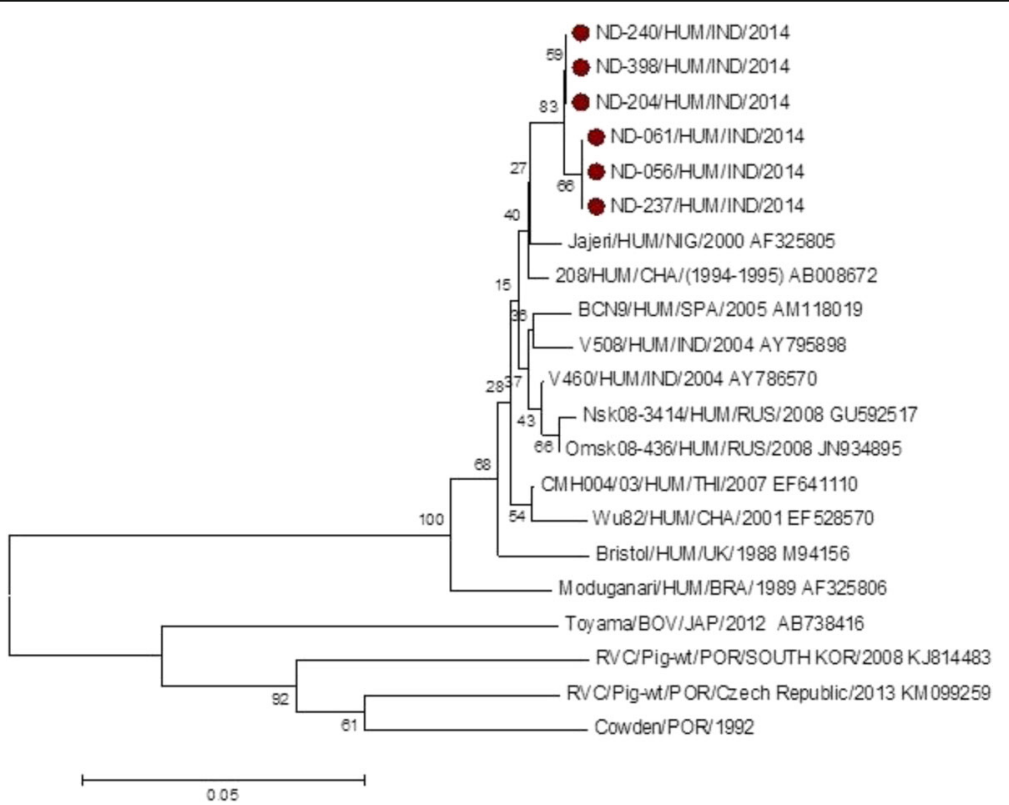

Fig. 2 Phylogenetic dendrogram of VP6 gene segment of group C rotavirus by neighbor joining method with MEGA 7.0 version software. The group C positive study samples are indicated by dark circles 


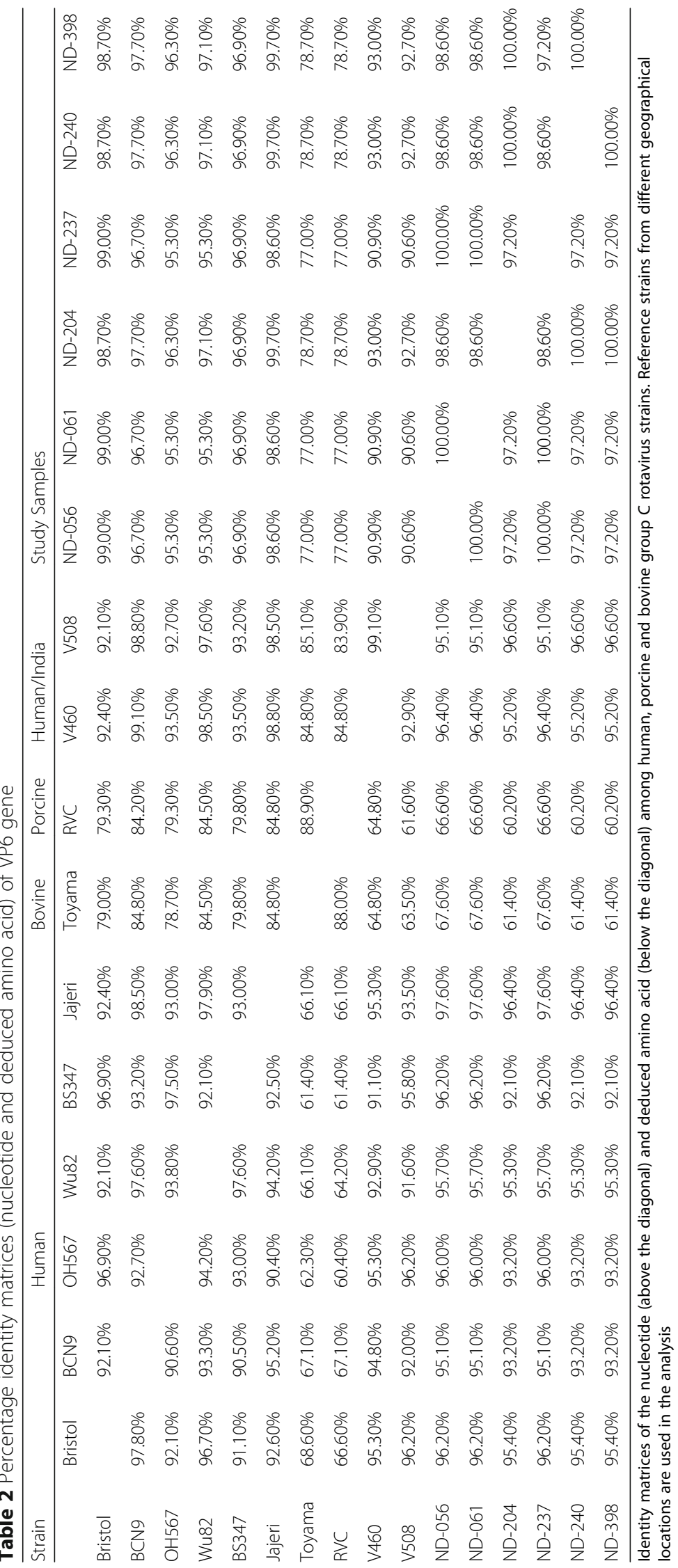




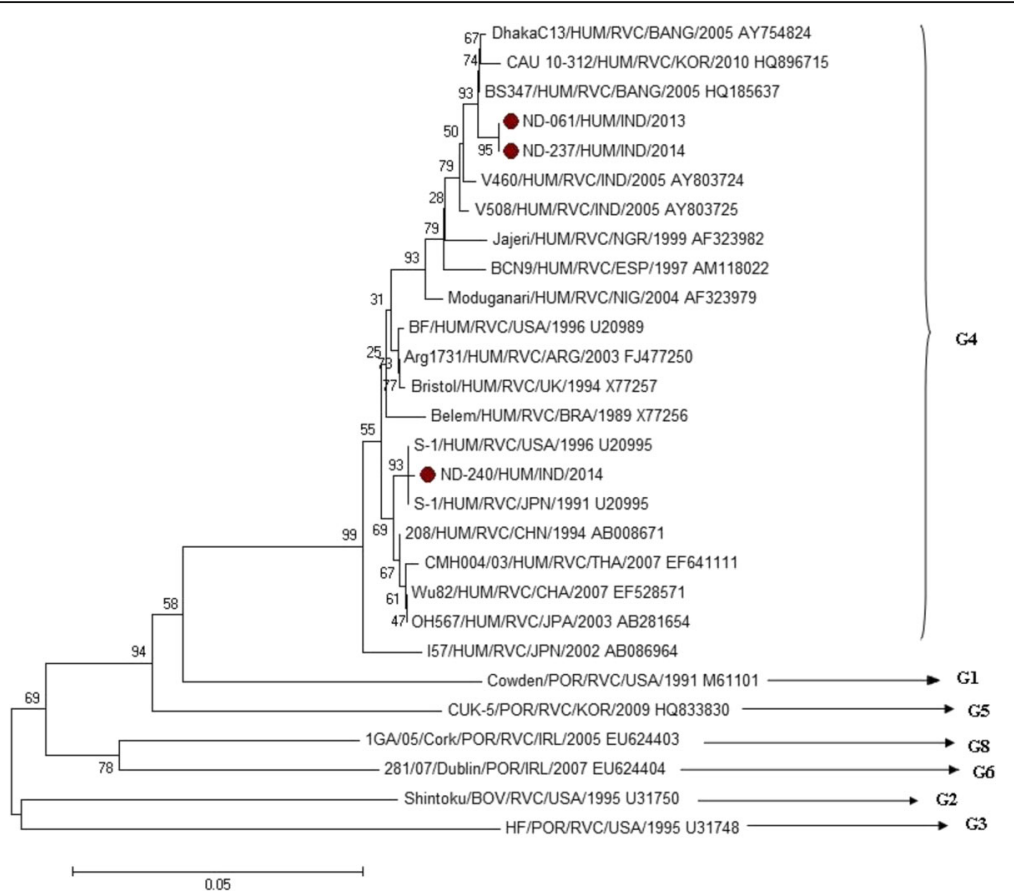

Fig. 3 Phylogenetic dendrogram of VP7 gene segment of group C rotavirus by neighbor joining method with MEGA 7.0 version software. The group C positive study samples are indicated by dark circles

level with Bangladeshi and USA strains [Table 3]. However, relatively less homology (96.90 to $97.80 \%$ nucleotide and 90.90 to $97.90 \%$ amino acid) was observed with Indian strains reported earlier [Table 3]. The animal RVC such as bovine (73.20 to $73.80 \%$ amino acid) and porcine (75.00 to $75.60 \%$ amino acid) strains were found distantly related. The VP7 sequence analysis of our study sample showed 98.20 to $100.0 \%$ nucleotide identity with each other.

\section{Phylogenetic and sequence analysis of VP4 gene}

The VP4 genes of the present RVC strains clustered with $\mathrm{P}[2]$ genotype which is the only known human $\mathrm{P}$ genotype [Fig. 4]. A close VP4 sequence homology

Table 3 Percentage identity matrices (nucleotide and deduced amino acid) of VP7

\begin{tabular}{|c|c|c|c|c|c|c|c|c|c|c|c|c|c|c|}
\hline \multirow[t]{2}{*}{ Strain } & \multirow[b]{2}{*}{ Bristol } & \multirow[b]{2}{*}{ BCN9 } & \multirow[b]{2}{*}{$\mathrm{OH} 567$} & \multirow[b]{2}{*}{ Wu82 } & \multicolumn{3}{|l|}{ Human } & \multirow{2}{*}{$\frac{\text { Porcine }}{\text { Cowden }}$} & \multirow{2}{*}{$\frac{\text { Bovine }}{\text { Shintoku }}$} & \multicolumn{2}{|c|}{ Human/India } & \multicolumn{3}{|c|}{ Study Samples } \\
\hline & & & & & BS347 & C13 & S-1 & & & V460 & V508 & ND-061 & ND-240 & ND-237 \\
\hline Bristol & & $96.70 \%$ & $98.20 \%$ & $98.20 \%$ & $96.70 \%$ & $96.30 \%$ & $98.20 \%$ & $75.10 \%$ & $79.00 \%$ & $96.70 \%$ & $96.70 \%$ & $97.10 \%$ & $98.40 \%$ & $97.10 \%$ \\
\hline BCN9 & $90.70 \%$ & & $95.30 \%$ & $95.30 \%$ & $97.30 \%$ & $96.90 \%$ & $95.30 \%$ & $74.20 \%$ & $78.60 \%$ & $97.60 \%$ & $97.60 \%$ & $97.70 \%$ & $98.90 \%$ & $97.70 \%$ \\
\hline $\mathrm{OH} 567$ & $95.00 \%$ & $95.80 \%$ & & $100.00 \%$ & $95.70 \%$ & $95.30 \%$ & $98.80 \%$ & $75.50 \%$ & $79.40 \%$ & $95.70 \%$ & $96.10 \%$ & $96.20 \%$ & $97.40 \%$ & $96.20 \%$ \\
\hline Wu82 & $95.00 \%$ & $93.80 \%$ & $100.00 \%$ & & $95.70 \%$ & $95.30 \%$ & $98.80 \%$ & $75.50 \%$ & $79.40 \%$ & $95.70 \%$ & $96.10 \%$ & $96.20 \%$ & $97.00 \%$ & $96.20 \%$ \\
\hline BS347 & $91.90 \%$ & $93.80 \%$ & $91.50 \%$ & $93.30 \%$ & & $99.60 \%$ & $96.10 \%$ & $75.00 \%$ & $78.40 \%$ & $99.20 \%$ & $98.40 \%$ & $98.40 \%$ & $98.60 \%$ & $98.40 \%$ \\
\hline C13 & $90.70 \%$ & $92.60 \%$ & $93.30 \%$ & $91.50 \%$ & $98.70 \%$ & & $95.70 \%$ & $74.60 \%$ & $78.00 \%$ & $98.80 \%$ & $98.00 \%$ & $98.00 \%$ & $98.20 \%$ & $98.00 \%$ \\
\hline$S-1$ & $95.00 \%$ & $95.80 \%$ & $96.20 \%$ & $96.20 \%$ & $90.70 \%$ & $94.50 \%$ & & $75.70 \%$ & $79.80 \%$ & $96.10 \%$ & $96.10 \%$ & $99.20 \%$ & $94.80 \%$ & $99.20 \%$ \\
\hline Cowden & $70.70 \%$ & $73.80 \%$ & $78.20 \%$ & $78.20 \%$ & $76.70 \%$ & $75.10 \%$ & $76.50 \%$ & & $79.40 \%$ & $75.10 \%$ & $75.10 \%$ & $73.00 \%$ & $74.10 \%$ & $73.00 \%$ \\
\hline Shintoku & $71.30 \%$ & $74.40 \%$ & $70.00 \%$ & $79.10 \%$ & $76.90 \%$ & $75.70 \%$ & $70.00 \%$ & $76.90 \%$ & & $78.80 \%$ & $78.20 \%$ & $77.80 \%$ & $78.40 \%$ & $77.80 \%$ \\
\hline V460 & $94.80 \%$ & $92.50 \%$ & $95.40 \%$ & $95.40 \%$ & $94.40 \%$ & $94.00 \%$ & $96.00 \%$ & $75.00 \%$ & $75.40 \%$ & & $98.80 \%$ & $97.60 \%$ & $97.80 \%$ & $97.60 \%$ \\
\hline V508 & $95.10 \%$ & $97.50 \%$ & $96.70 \%$ & $95.70 \%$ & $97.10 \%$ & $97.80 \%$ & $98.30 \%$ & $77.10 \%$ & $76.70 \%$ & $98.70 \%$ & & $96.90 \%$ & $97.10 \%$ & $96.90 \%$ \\
\hline ND-061 & $95.50 \%$ & $97.40 \%$ & $96.40 \%$ & $96.40 \%$ & $96.90 \%$ & $95.70 \%$ & $97.60 \%$ & $75.60 \%$ & $73.80 \%$ & $92.50 \%$ & $90.90 \%$ & & $98.20 \%$ & $100.00 \%$ \\
\hline ND-240 & $98.80 \%$ & $97.70 \%$ & $95.70 \%$ & $95.80 \%$ & $95.10 \%$ & $96.20 \%$ & $97.00 \%$ & $75.00 \%$ & $73.20 \%$ & $97.90 \%$ & $96.50 \%$ & $96.20 \%$ & & $98.20 \%$ \\
\hline ND-237 & $95.50 \%$ & $97.40 \%$ & $96.40 \%$ & $96.40 \%$ & $96.90 \%$ & $95.70 \%$ & $97.60 \%$ & $75.60 \%$ & $73.80 \%$ & $92.50 \%$ & $90.90 \%$ & $100.00 \%$ & $96.50 \%$ & \\
\hline
\end{tabular}




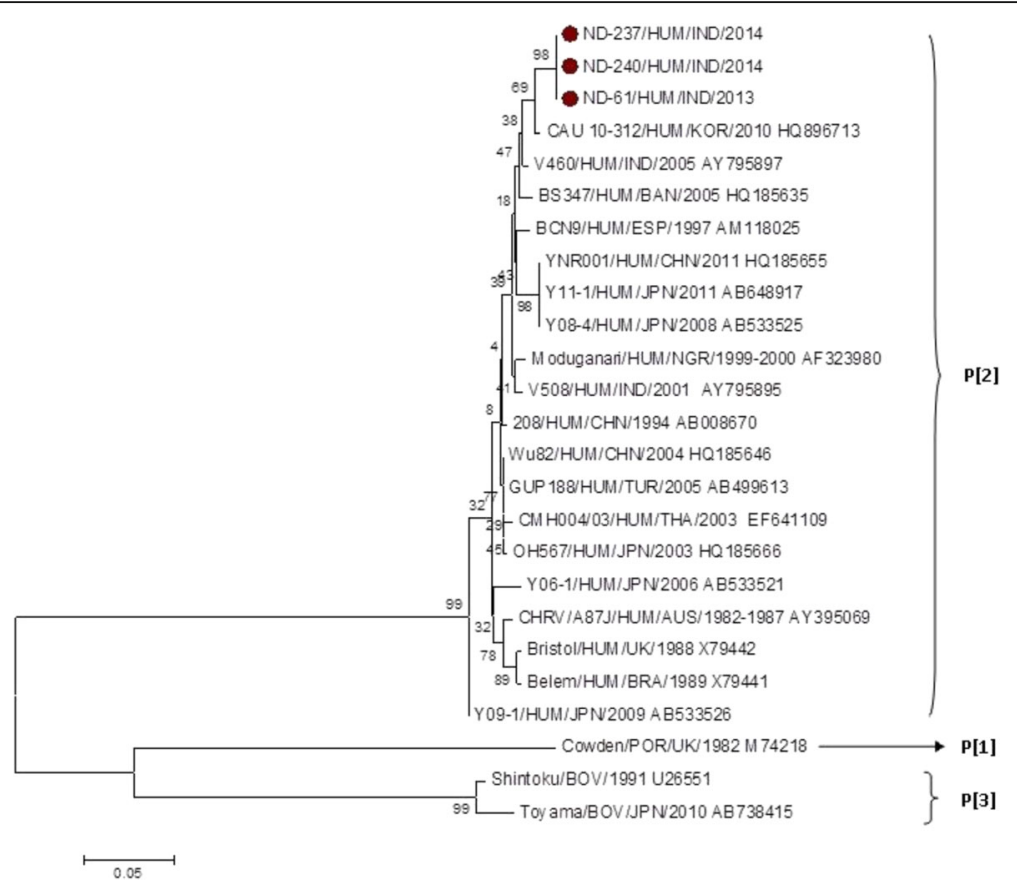

Fig. 4 Phylogenetic dendrogram of VP4 gene segment of group C rotavirus by neighbor joining method with MEGA 6.0 version software. The group C VP4 positive samples of our study are indicated by dark circles

was observed with Korean strain "CAU 10-312" both at nucleotide (98.70 to $99.50 \%$ ) and amino acid (97.60 to 98.20\%) level [Table 4]. However, relatively less homology (nucleotide identity of 97.30 to $98.10 \%$ and amino acid identity 96.30 to $97.90 \%$ ) was observed with previously reported Indian strains. Similar to the VP6 and VP7 genes the VP4 gene of animal RVC were also found distantly related to the present RVC; for example amino acid identity of 66.80 to $67.40 \%$ and 68.10 to $68.70 \%$ were observed with bovine and porcine strains respectively [Table 4]. Of note, VP4 gene of ND-061 and ND-237 were also found identical as seen in case of VP7.

For all the three genes VP6, VP7 and VP4, both bovine and porcine strains formed the two separate cluster groups and had poor homology with the human strains [Table 5].

Table 4 Percentage identity matrices (nucleotide and deduced amino acid) of VP4 gene

\begin{tabular}{|c|c|c|c|c|c|c|c|c|c|c|c|c|c|}
\hline \multirow[t]{2}{*}{ Strains } & \multirow[b]{2}{*}{ Bristol } & \multirow[b]{2}{*}{ BCN9 } & \multicolumn{4}{|l|}{ Human } & \multirow{2}{*}{$\begin{array}{l}\text { Porcine } \\
\text { Cowden }\end{array}$} & \multirow{2}{*}{$\begin{array}{l}\text { Bovine } \\
\text { Shintoku }\end{array}$} & \multicolumn{2}{|c|}{ Human/India } & \multicolumn{3}{|c|}{ Study Samples } \\
\hline & & & $\mathrm{OH} 567$ & Wu82 & BS347 & CAU 10-312 & & & V460 & V508 & ND-061 & ND-240 & ND-237 \\
\hline Bristol & & $97.00 \%$ & $97.00 \%$ & $97.60 \%$ & $96.10 \%$ & $96.50 \%$ & $69.20 \%$ & $65.20 \%$ & $96.60 \%$ & $97.00 \%$ & $98.40 \%$ & $99.90 \%$ & $98.40 \%$ \\
\hline BCN9 & $91.90 \%$ & & $97.80 \%$ & $98.50 \%$ & $97.80 \%$ & $97.40 \%$ & $68.80 \%$ & $64.40 \%$ & $98.30 \%$ & $98.70 \%$ & $97.90 \%$ & $98.20 \%$ & $97.90 \%$ \\
\hline OH567 & $91.90 \%$ & $94.60 \%$ & & $99.30 \%$ & $97.00 \%$ & $97.00 \%$ & $69.00 \%$ & $65.00 \%$ & $97.40 \%$ & $98.20 \%$ & $98.20 \%$ & $98.40 \%$ & $98.20 \%$ \\
\hline Wu82 & $93.20 \%$ & $95.90 \%$ & $98.60 \%$ & & $97.60 \%$ & $97.60 \%$ & $69.20 \%$ & $65.00 \%$ & $98.00 \%$ & $98.50 \%$ & $97.70 \%$ & $98.90 \%$ & $97.70 \%$ \\
\hline BS347 & $89.90 \%$ & $93.90 \%$ & $92.60 \%$ & $93.90 \%$ & & $97.40 \%$ & $68.80 \%$ & $64.40 \%$ & $97.80 \%$ & $97.80 \%$ & $97.10 \%$ & $98.40 \%$ & $97.10 \%$ \\
\hline CAU 10-312 & $91.20 \%$ & $92.60 \%$ & $92.60 \%$ & $93.90 \%$ & $93.20 \%$ & & $69.20 \%$ & $65.20 \%$ & $97.80 \%$ & $97.40 \%$ & $98.70 \%$ & $99.50 \%$ & $98.70 \%$ \\
\hline Cowden & $69.70 \%$ & $69.10 \%$ & $69.70 \%$ & $69.70 \%$ & $67.20 \%$ & $60.30 \%$ & & $75.70 \%$ & $69.00 \%$ & $69.20 \%$ & $66.80 \%$ & $67.80 \%$ & $66.80 \%$ \\
\hline Shintoku & $69.00 \%$ & $67.80 \%$ & $69.00 \%$ & $69.00 \%$ & $67.80 \%$ & $69.60 \%$ & $77.30 \%$ & & $64.60 \%$ & $64.80 \%$ & $63.20 \%$ & $63.60 \%$ & $63.20 \%$ \\
\hline V460 & $90.60 \%$ & $94.60 \%$ & $93.30 \%$ & $94.60 \%$ & $94.00 \%$ & $94.00 \%$ & $69.10 \%$ & $67.80 \%$ & & $98.30 \%$ & $97.30 \%$ & $98.00 \%$ & $97.30 \%$ \\
\hline V508 & $92.60 \%$ & $96.60 \%$ & $95.30 \%$ & $96.60 \%$ & $94.60 \%$ & $93.20 \%$ & $69.10 \%$ & $67.80 \%$ & $95.30 \%$ & & $98.10 \%$ & $97.40 \%$ & $98.10 \%$ \\
\hline ND-061 & $92.50 \%$ & $95.90 \%$ & $94.50 \%$ & $95.90 \%$ & $95.90 \%$ & $98.20 \%$ & $68.10 \%$ & $66.80 \%$ & $97.30 \%$ & $96.50 \%$ & & $97.20 \%$ & $100.00 \%$ \\
\hline ND-240 & $93.80 \%$ & $97.20 \%$ & $95.90 \%$ & $97.20 \%$ & $97.20 \%$ & $97.60 \%$ & $68.70 \%$ & $67.40 \%$ & $96.30 \%$ & $97.90 \%$ & $99.50 \%$ & & $98.20 \%$ \\
\hline ND-237 & $92.50 \%$ & $95.90 \%$ & $94.50 \%$ & $95.90 \%$ & $95.90 \%$ & $98.20 \%$ & $68.10 \%$ & $66.80 \%$ & $97.30 \%$ & $96.50 \%$ & $100.00 \%$ & $99.50 \%$ & \\
\hline
\end{tabular}


Table 5 Comparative sequence identities (\%) of the rotavirus group C study strains with that of human, bovine and porcine strains from other studies

\begin{tabular}{lllllll}
\hline & Human Strains & \multicolumn{3}{c}{ Bovine } & \multicolumn{2}{l}{ Porcine } \\
\hline Gene & Nucleotide & Amino acid & Nucleotide & Amino acid & Nucleotide & Amino acid \\
VP4 & $96.10-100$ & $89.90-100$ & $63.20-65.20$ & $66.80-69.60$ & $66.80-69.20$ & $60.30-69.70$ \\
VP6 & $90.60-100$ & $90.40-100$ & $77.0-85.80$ & $61.40-68.60$ & $77.0-84.80$ & $60.20-67.10$ \\
VP7 & $94.10-100$ & $91.50-100$ & $77.8-79.4$ & $70.0-79.1$ & $83.80-85.50$ & $70.70-78.20$ \\
\hline
\end{tabular}

The human strains include Bristol, BCN9, BS347, OH567, Wu82, V508 and V460, ND-061, ND-204, ND-398, ND-237, ND-056, ND-240

Table 6 describes the clinical details of the RVC negatives (including group A positives) and RVC positive patients. Our data indicated that the boys were at higher risk of getting RVC infection than girls. The dehydration was found more severe in RVC positive patients than in RVC negative patients. However, this difference was not statistically significant. Other clinical parameters like age, duration of diarrhea, vomiting days and episodes and treatment are similar in both groups of patients [Table 6].

\section{Discussion}

Since the first outbreak of group $C$ rotavirus in the year 1980, in USA, there have been various outbreaks reported from different parts of the world. The serosurveillance study conducted in Sweden reported group C prevalence ranging from 35 to $45 \%$ depending on age [19]. A survey in UK reported the group C seroprevalence of $43 \%$ in all age groups and $66 \%$ for $71-75$ years age group [20]. The detection of group $C$ rotavirus and its prevalence has been extensively studied in many countries worldwide. However, its prevalence in India remains largely unknown. Very recently around the same time as our study, another study was conducted in Western India also detected RVC in a group of patients aged 9 months to 86 years [21]. The present study for the first time is conducted in Northern India that identifies group $\mathrm{C}$ rotavirus as the etiological agent of severe diarrhea in children in Delhi. Jiang et al. in [22] and Martella et al. in [23] proposed a classification of RVC and accordingly group $\mathrm{C}$ rotaviruses were further classified into G (VP7) and P (VP4) genotypes similar to group A rotavirus [22, 23]. Earlier studies had shown a total of 9 ' $\mathrm{G}$ ' and 3 ' $\mathrm{P}$ ' genotypes of RVC including humans and animals strains [9, 20-25]. All previous reports (Jiang et al. in [22], Martell et al. in [23] and Luchs et al. in [26]) showed that the human RVC strains fall into a single ' $\mathrm{G}$ ' (G4) and single 'P' (P[2]) genotype. On the contrary, animal RVC strains fall into multiple G/P types. For example, bovine strains are G2P[3] and porcine strains are G1,G3,G5,G6;P[1] genotypes [22, 23, 26]. All earlier studies conducted worldwide had demonstrated the phylogenetic relatedness among human RVC strains [27-30]. Our results further confirmed the earlier reports including that of Yamamoto D et al. and Luchs et al. on human group C rotavirus VP7 and VP4 genes being highly conserved clustering to G4P[2] genotype $[9,25]$. Additionally our nucleotide and phylogenetic data showed that VP4, VP6 and VP7 genes were more closely related within themselves as contrary to what has been reported earlier. This may be attributed to the different geographical locations. However, according to Khamrin et al., group $\mathrm{C}$ rotavirus strains from animals remain different from the human RVC strains [31]. The differences in sequence homology with respect to VP7 (close to Bangladeshi and USA strains) and VP6 (close to Nigerian and Chinese strain) genes clearly showed differences in their origin. The phylogenetic dendrogram of VP6 gene of ND isolates showed higher sequence homology with Nigerian strain "jajeri"

Table 6 Comparison of demographic and clinical characteristics of children having acute RVC diarrhea with that of unknown etiology

\begin{tabular}{|c|c|c|c|}
\hline \multirow[t]{2}{*}{ Parameters } & \multirow{2}{*}{$\begin{array}{l}\text { RVC negative } \\
\text { patients }(n=344)\end{array}$} & \multirow{2}{*}{$\begin{array}{l}\text { RVC positive } \\
\text { patients }(n=6)\end{array}$} & \\
\hline & & & \\
\hline Gender (Male/Female) & $64.8 \% / 35.17 \%$ & $66.7 \% / 33.3 \%$ & \\
\hline Age (mean $\pm \mathrm{SD}$ ) (months) & $12.39( \pm 8.41)$ & $17( \pm 11.15)$ & $p(0.09)$ \\
\hline Days of Diarrhea (mean \pm SD) & $2.85 \pm 1.95$ & $4.33 \pm 2.94$ & $p(0.06)$ \\
\hline Episodes (mean \pm SD) & $16.08 \pm 8.05$ & $20.67 \pm 10.72$ & $p(0.16)$ \\
\hline Severe Dehydration & $72.20 \%$ & $100 \%$ & \\
\hline Days of vomiting (mean $\pm S D$ ) & $1.95 \pm 1.70$ & $1 \pm 1.26$ & $p(0.17)$ \\
\hline Episodes/day (mean \pm SD) & $5.26 \pm 4.26$ & $4.5 \pm 5.92$ & $p(0.67)$ \\
\hline Treatment (Oral/Intravenous) & $24.7 \% / 75.29 \%$ & $16.6 \% / 83.3 \%$ & \\
\hline
\end{tabular}


a

Jajeri/HOM/NIG/2000 AF325805 Bristol/HUM/UK/1988 M94156 Wu82/HUM/CHA/2001 EF528570 BCH9/HOM/ESP/2005 AM118019 V460/HOM/IND/2004 AY786570 V508/HOM/IND/2004 AY795898 BS347/HUM/BANG/2005 HO18563 OH567/HOM/JPA/2003 HO185667

ND-204/HUM/TMD / 2014

ND-056/HUM/IND/2013

ND-237/HUM/TIND/2014

ND-398/HUM/IIND/2014

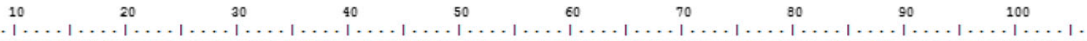

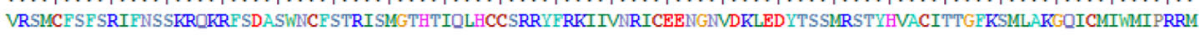

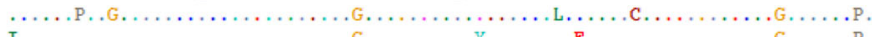

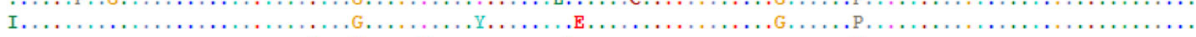

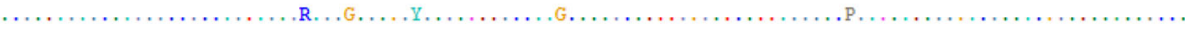

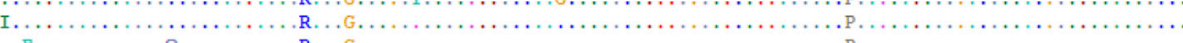

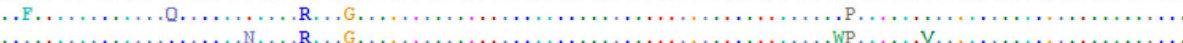

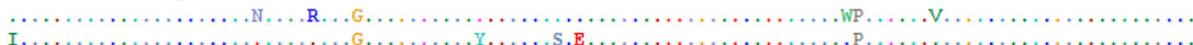

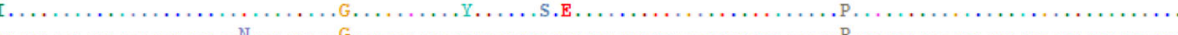

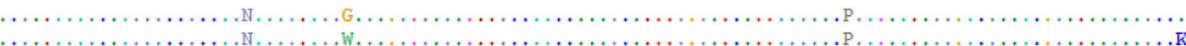
… (1) b

Bristol/HUM/RVC/UK/1994 X77257 BCN9/HUM/RVC/ESP/1997 AM118022 OH567/HUM/RVC/JPA/2003 AB28165 Wu82/HUM/RVC/CHA/2007 EF528571 BS347/HUM/RVC/BANG/2005 HQ1856 C13/HUM (BANG) 2005

$\mathrm{S}-1 /$ HUM (JPN) 1991

V508/HUM/RVC/IND/2005 AY803725 V460/HUM/RVC/IND/2005 AY803724 ND-061/HUM/IND/2013

ND $-237 / \mathrm{HUM} / \mathrm{IND} / 2014$

ND $-240 / \mathrm{HUM} / \mathrm{IND} / 2014$

Bristol/HUM/RVC/UK/1994 X77257 BCN9/HUM/RVC/ESP/1997 AM118022 OH567/HUM/RVC/JPA/2003 AB28165 Wu82/HUM/RVC/CHA/2007 EF528571 BS347/HUM/RVC/BANG/2005 HQ1856 C13/HUM (BANG) 2005

S-1/HUM (JPN) 1991

V508/HUM/RVC/IND/2005 AY803725

V460/HUM/RVC/IND/2005 AY803724

ND-061/HUM/IND/2013

ND $-237 / \mathrm{HUM} / \mathrm{IND} / 2014$

ND $-240 / \mathrm{HUM} / \mathrm{IND} / 2014$

\section{C}

Bristol/HUM/UK/1988 X79442 BCN9/HUM/ESP/1997 AM118025 OH567/HUM/JPN/2003 HQ185666 Wu82/HUM/CHN/2004 HQ185646 BS347/HUM/BAN/2005 HQ185635 CAU 10-312/HUM/KOR/2010 HQ8967 V460/HUM/IND/2005 AY795897 V508/HUM/IND/2001 AY795895 ND-061/HUM/IND/2014 ND-237/HUM/IND/2014 ND-240/HUM/IND/2014

Bristol/HUM/UK/1988 X79442 BCN9/HUM/ESP/1997 AM118025 OH567/HUM/JPN/2003 HQ185666 Wu $82 / \mathrm{HUM} / \mathrm{CHN} / 2004 \mathrm{HQ} 185646$ BS347/HUM/BAN/2005 HQ185635 CAU 10-312/HUM/KOR/2010 HQ8967 V460/HUM/IND/2005 AY795897 V508/HUM/IND/2001 AY795895 ND-061/HUM/IND/2014 ND-237/HUM/IND/2014

ND-240/HUM/IND/2014

Fig. 5 Deduced amino acid sequence alignment of (a): VP6, (b): VP7 and (c): VP4 genes of previous Indian RVC strains and strains from our study. The dots represent the identical amino acids

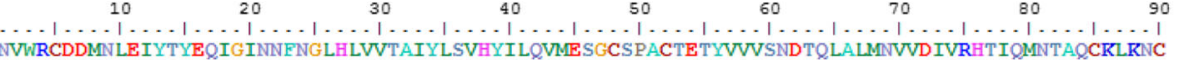

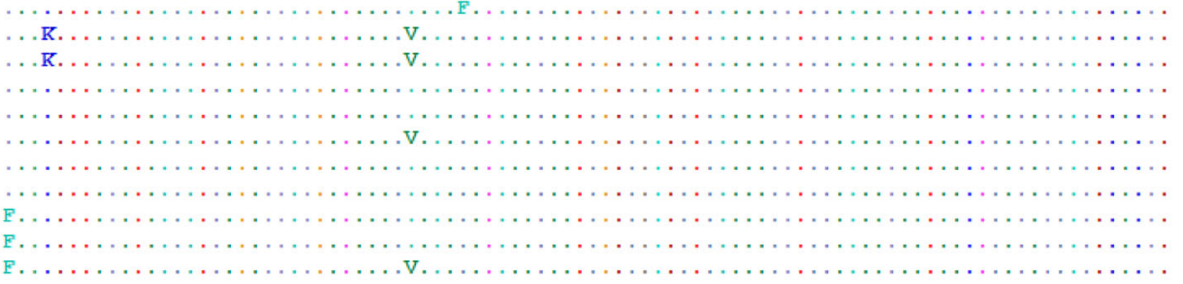

$\begin{array}{llllllll}100 & 110 & 120 & 130 & 140 & 150 & 160 & 170\end{array}$

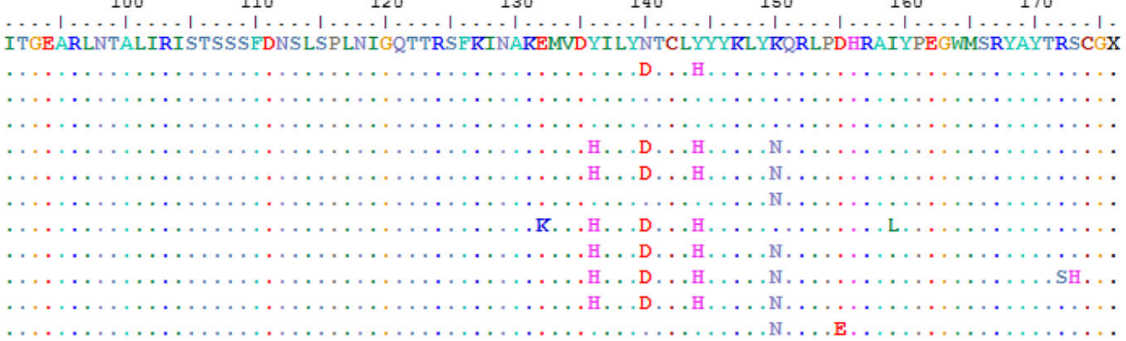

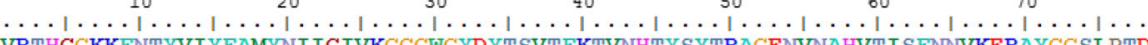

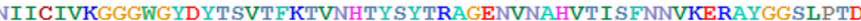

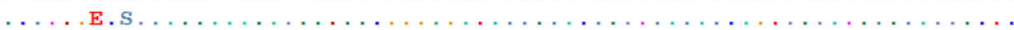
גל גים

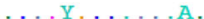
............

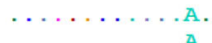

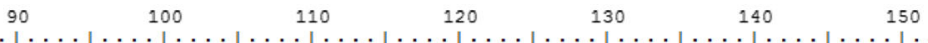

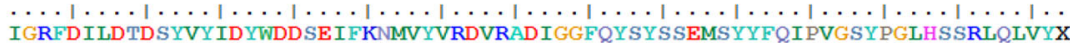

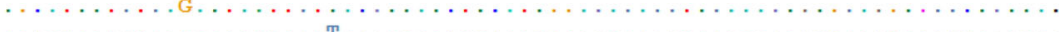

$\ldots \ldots \ldots \ldots$

…

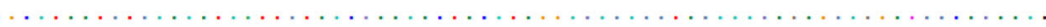

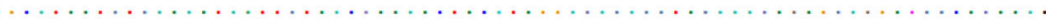

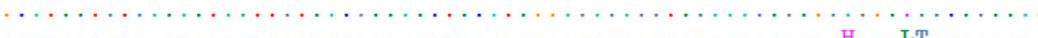

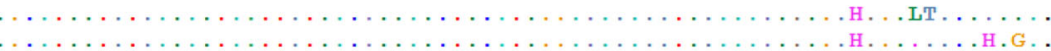

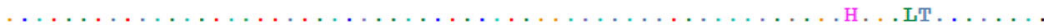


and Chinese strain "208" as compared to previously reported Indian strains indicating difference in emergence. The VP7 gene analysis further illustrated that the study strains fall into two different groups, one was found to be more closely related to Bangladeshi strain "Dhaka C13" while the second group was found clustering with USA strains suggesting two separate sources of origin. The molecular data of animal and human group $\mathrm{C}$ rotaviruses will help to further elucidate the origin of human RVC. As anticipated, substitutions in the deduced amino acid sequences were more variable in VP7 and VP4 as compared to VP6 sequences [Figs. 5a, b and c]. This indicates that the genes VP7 and VP4 have evolved more over the period of time from the year 2001 to 2014 whereas the evolution or genetic drift in VP6 gene is slow.

RVCs have been found as important enteric pathogens because they cause diarrhea in all age groups, including adults, [32-34]. However, RVC are mostly detected in children above 4 years of age [11, 14]. Our study also detected group $\mathrm{C}$ rotavirus in children from 3 months to 2.8 years age group. This shows that the children less than 4 years old may be at greater risk of getting infected with RVC.

Some of the group C VP6 positive sample in the present study could not be amplified with the VP4 and VP7 genotyping primers. This can be attributed to sequence difference(s) in the primer binding region. Luchs and Timenetsky in [26] also reported non-typeable strains of group C rotavirus in Brazil [25]. Sequence analysis of other RV genes from these samples is in progress which will help us to understand their diversity and elucidate their origin. Given that RVC often appear unstable, screening of larger number of samples will help to determine the true estimate of disease burden due to RVC in India.

Our study emphasizes the need to conduct more surveillance studies and detailed investigations on group $C$ rotavirus, initially in the sentinel sites that can be further extended to other geographical locations in India. This will help in estimating the actual load of gastroenteritis in Indian population and will also help to understand whether the new Indian rotavirus vaccine $\left(\right.$ Rotavac $^{\circ}$ ) has the ability to cross protect other groups of rotaviruses in humans.

\section{Conclusion}

Our study demonstrated group $\mathrm{C}$ rotavirus as the cause of severe diarrhea in children in Delhi and emphasizes the need to determine the disease burden using a sensitive and reliable diagnostic test.

\section{Abbreviations}

PAGE: Polyacrylamide gel electrophoresis; RT-PCR: Reverse transcription polymerase chain reaction; RVC: Group C rotavirus

\section{Acknowledgements}

We acknowledge the Indian Council of Medical Research (ICMR), Government of India for providing financial support to PR for carrying out this work.

\section{Funding}

Research grant to PR from Indian Council of Medical Research, Government of India.

Availability of data and materials

All data generated or analyzed during this study are included in this article.

\section{Authors' contributions}

VRT has conducted all the experiments and prepared the draft of the manuscript. PR is the PI of the grant; she has conceived and designed the study and overall supervised and edited the manuscript. BJ has helped in developing protocol and participated in drafting the manuscript for important intellectual content. MK, AB, SA and PK have contributed as clinical investigators in study design. All authors have read and approved the final manuscript.

\section{Competing interests}

The authors declare that they have no competing interests in this section.

Consent for publication

Not applicable.

Ethics approval and consent to participate

The study was ethically approved by the institute's ethics committee of All India Institute of Medical Sciences (AllMS) (Reference No: IESC/T-321/ 02.08.2013)

The Clinical information was recorded from the enrolled subjects. A written informed consent was also obtained from one of the parents of the child before enrollment.

\section{Publisher's Note}

Springer Nature remains neutral with regard to jurisdictional claims in published maps and institutional affiliations.

\section{Author details}

'Department of Biotechnology, Faculty of Science, Jamia Hamdard University, Hamdard Nagar, New Delhi 110062, India. ${ }^{2}$ Department of Pediatrics, All India Institute of Medical Sciences, New Delhi, India. ${ }^{3}$ Centers for Disease Control and Prevention, Atlanta, USA. 'Kalawati Saran Children's Hospital, Lady Hardinge Medical College, New Delhi, India.

Received: 9 February 2017 Accepted: 22 May 2017

Published online: 30 May 2017

\section{References}

1. Saif $L$, Bohl EH, Theil KW, Cross RF, House JA. Rotavirus like, calicivirus-like, and 23-nm virus-like particles associated with diarrhea in young pigs. J Clin Microbiol. 1980;12:105-11.

2. Rodger SM, Bishop RF, Holmes IH. Detection of a rotavirus like agent associated with diarrhea in an infant. J Clin Microbiol. 1982;16:724-6.

3. Cunliffe NA, Dove W, Jiang B, Thinwda Cert BD, Broadhead RL, Molyneux $M E$, et al. Detection of group $C$ rotavirus in children with acute gastroenteritis in Blantyre, Malawi. J Pediatr Infect Dis. 2001;20:1088-90.

4. Phan TG, Nishimura S, Okame M, Nguyen TA, Khamrin P, Okitsu Maneekarn $\mathrm{N}$, et al. Virus diversity and an outbreak of group $\mathrm{C}$ rotavirus among infants and children with diarrhea Maizuru city, Japan during 2002-2003. J Med Virol. 2004;74:173-9.

5. Schnagl RD, Boniface K, Cardwell P, McCarthy D, Ondracek C, Coulson B, et al. Incidence of group $\mathrm{C}$ human rotavirus in central Australia and sequence variation of the VP7 and VP4 genes. J Clin Microbiol. 2004;42:2127-33.

6. Steyer A, Poljsak-Prijatelj M, Bufon T, Sedmak M, Vidmar L, Mijovski JZ, et al. First detection of group $\mathrm{C}$ rotavirus in patients with gastroenteritis in Slovenia. J Med Virol. 2006;78:1250-5.

7. Abid I, Guix S, Aouni M, Pintó R, Bosch A. Detection and characterization of human group $C$ rotavirus in the pediatric population of Barcelona, Spain. J Clin Virol. 2007;38:78-82. 
8. Jeong YJ, Park SI, Hosmillo M, Shin DJ, Chun YH, Kim HJ, et al. Detection and molecular characterization of porcine group $\mathrm{C}$ rotaviruses in South Korea. Vet Microbiol. 2009;138:217-24.

9. Yamamoto D, Ghosh S, Kuzuya M, Wang YH, Zhou X, Chawla Sarkar M, et al. Whole genome characterization of human group $C$ rotavirus: identification of two lineages in the VP3 gene. J Gen Virol. 2011;92:361-9.

10. Riepenhoff-Talty M, Gouvea V, Evans MJ, Svensson L, Hoffenberg E, Sokol RJ, et al. Detection of Group C Rotavirus in Infants with Extrahepatic Biliary Atresia. J Infect Dis. 1996;174:8-15.

11. Oishi I, Yamazaki K, Minekawa Y. An occurrence of diarrheal associated group C rotavirus in adults. Microbiol Immunol. 1993;37:505-9.

12. de Zoysa I, Feachem RV. Interventions for the control of diarrhoeal diseases among young children: rotavirus and cholera immunization. Bull WHO. 1985;63:569-83.

13. Ishimaru Y, Nakano S, Nakano H, Oseta M, Yamashita Y. Epidemiology of group C rotavirus in Matsuyama, Japan. Acta Paediatr Jpn. 1991;33:50-6.

14. Jiang B, Dennehy Penelope H, Spangenberger S, Gentsch JR, Glass RI. First detection of group $C$ rotavirus in fecal specimens of children with diarrhea in the United States. J Infect Dis. 1995;172:45-50.

15. Matthijnssens J, Ciarlet M, Rahman M, Attoui H, Banyai K, Estes MK, et al. Recommendations for the classification of group A rotaviruses using all 11 genomic RNA segments. Arch Virol. 2008;153:1621-9.

16. Ghosh S, Kobayashi N. Whole-genomic analysis of rotavirus strains: Current status and future prospects. Future Microbiol. 2011;6:1049-65.

17. Tiku VR, Sharma S, Verma A, Kumar P, Raghavendhar S, Aneja S, et al. Rotavirus diversity among diarrheal children in Delhi, India during 2007-2012. Vaccine. 2014:32:A62-7.

18. Sanchez-Fauquier A, Roman E, Colomina J, Wilhelmi I, Glass RI, Jiang B. First detection of group $C$ rotavirus in children with acute diarrhea in Spain. Arch Virol. 2003;148:399-404.

19. Nilsson M, Svensson L. Antibody prevalence and specificity against group C rotavirus. Glasgow: Program and abstracts of the IXth International Congress of Virology; 1993. p. P54-7.

20. James VLA, Lambden PR, Caul EO, Cooke SJ, Clarke IN. Seroepidemiology of human group C rotavirus in the UK. J Med Virol. 1997;52:86-91.

21. Joshi MS, Jare VM, Gopalkrishna V. Group C rotavirus infection in patients with acute gastroenteritis in outbreaks in western India between 2006 and 2014. Epidemiol Infect. 2017;145:310-5.

22. Jiang B, Gentsch JR, Tsunemitsu H, Saif LJ, Glass RI. Sequence analysis of the gene encoding VP4 of a bovine group $C$ rotavirus: Molecular evidence for a new P genotype. Virus Genes. 1999;19:85-8.

23. Martella V, Banyai K, Lorusso E, Decaro N, Bellacicco A, Desario C, et al. Genetic heterogeneity in the VP7of group C rotaviruses. Virology. 2007;367:358-66.

24. Rahman M, Banik S, Faruque AS, Taniquchi K, Sack DA, Van Ranst M, et al. Detection and characterization of Human group C rotaviruses in Bangladesh. J Clin Microbiol. 2005:43:4460-5.

25. Marthaler D, Rossow K, Culhane M, Collins J, Goyal S, Ciarlet M, et al. Identification, phylogenetic analysis and classification of porcine group C rotavirus VP7 sequences from the US and Canada. Virology. 2013;446:189-98.

26. Luchs A, Do-Carmo-Sampaio-Tavares-Timenetsky M. Phylogenetic analysis of human group $\mathrm{C}$ rotavirus circulating Brazil reveals a potential unique NSP4 genetic variant and high similarity with Asian strains. Mol Genet Genomics. 2015;290:969-86.

27. Adah MI, Wade A, Oseto M, Kuzuya M, Taniguchi K. Detection of human group $C$ rotaviruses in Nigeria and sequence analysis of their genes encoding VP4, VP6, and VP7 proteins. J Med Virol. 2002;66(2):269-75.

28. Wu H, Taniguchi K, Urasawa T, Urasawa S. Serological and genomic characterization of human rotaviruses detected in China. J Med Virol. 1998;55:168-76

29. Jiang B, Tsunemitsu H, Dennehy PH, Oishi I, Brown D, Schnagl RD, et al. Sequence conservation and expression of the gene encoding the outer capsid glycoprotein among human group C rotaviruses of global distribution. Arch Virol. 1996;141:381-90.

30. Baek IH, Than VT, Kim H, Lim I, Kim W. Full genomic characterization of a group C rotavirus isolated from a child in South Korea. J Med Virol. 2013; 85(8):1478-84

31. Khamrin P, Peerakome S, Malasao R, Mizuguchi M, Okitsu S, Ushijima H, et al. Genetic characterization of group $C$ rotavirus isolated from a child hospitalized with acute gastroenteritis in Chiang Mai, Thailand. Virus Genes. 2008:37:314-21.
32. Kuzuya M, Fujii R, Hamano M, Yamada M, Shinozaki K, Sasagawa A, et al. Survey of human group C rotaviruses in Japan during the winter of 1992 to 1993. J Clin Microbiol. 1998;36:6-10

33. Matsumoto K, Hatano M, Kobayashi K, Hasegawa A, Yamazaki S, Nakata S, 6, et al. An outbreak of gastroenteritis associated with acute rotaviral infection in school children. J Infect Dis. 1989;160:11-5.

34. Nilsson M, Svenungsson B, Hedlund KO, Uhnoo I, La Gergren A, Akre T, et al. Incidence and genetic diversity of group C rotavirus among adults. J Infect Dis. 2000:182:678-84.

\section{Submit your next manuscript to BioMed Central and we will help you at every step:}

- We accept pre-submission inquiries

- Our selector tool helps you to find the most relevant journal

- We provide round the clock customer support

- Convenient online submission

- Thorough peer review

- Inclusion in PubMed and all major indexing services

- Maximum visibility for your research

Submit your manuscript at www.biomedcentral.com/submit
) Biomed Central 